\title{
Science Teaching Aid Kit Made of Recycled Materials: Solution to Improve Conclusions Making Skill Through Practicums at Home During the Covid-19 Pandemic
}

\author{
Wirawan Fadly ${ }^{1}$, Ulfa Nur Hamidah ${ }^{2}$, Titah Sayekti ${ }^{3}$, \\ Muhamad Khoirul Anwar ${ }^{4}$, Aldila Candra Kusumaningrum ${ }^{5}$ \\ Islamic State Institute (IAIN) Ponorogo, East Java $a^{1,2,3,4,5}$ \\ \{wira1fadly@iainponorogo.ac.id ${ }^{1}$, ulfaabid5@gmail.com², sayekti.bio18@gmail.com³
}

\begin{abstract}
Covid-19 brings challenges to science practicum activities, which were initially carried out in laboratory to become at home. With this drastic change in learning, development research will be carried out in the manufacture of science teaching Aid Kit made from recycled materials that are practical and effective in increasing the ability to make student conclusions on pressure material for grade $8^{\text {th }}$ at one of the Islamic Junior High Schools (MTs) in Ponorogo. The research method used was R\&D through questionnaires and tests, then analyzed using qualitative descriptive statistics, quantitative descriptive, and inferential statistics using the t-test. The results of the study showed that science teaching aid kit developed practical and effective use showed a better difference in increasing the ability to conclusion making significantly $(\alpha=0.05)$ and the acquisition of an NGain value of 68.93 or in the moderate improvement category.
\end{abstract}

Keywords: Science Teaching Aid Kit; Recycled Materials; Conclusions Making Skills

\section{Introduction}

The Covid-19 pandemic is a necessity that must be faced by all communities and several sectors globally in 2020, including in the education sector which has a learning community [1]. The perceived impact on the education sector is that there is a pattern of drastic change in learning activities, which was initially carried out at school through face-to-face learning into learning activities at home through virtual face-to-face. Changes in the pattern of these activities are carried out to minimize the spread of Covid-19.

Frontal adaptation needs to be done so that learning can run amid in all the limitations of learning interactions. Based learning theory may be replaced through presentations and discussions by utilizing the platform learning management system (LMS). However, learning science-based on practicum activities are a dilemma because the learning is done through a practicum. The science practicum has the main objective of introducing the tools for practicum materials as well as how to work and the benefits as well as the relationship of all kinds of laboratory equipment with the concepts that have been or are being studied [2], [3]. Science 
practicum learning is done to train a process of observation and investigation that aims to build a scientific attitude and apply for scientific work in discovering a concept which in this case is a product of science [4].

In face-to-face learning, the teaching aids and practicum tools in the laboratory are indeed very helpful in clarifying the teaching materials delivered by educators and can provide real experiences to students and stimulate their thinking [5]. However, at present in the middle of the pandemic Covid-19 then the role of laboratory equipment can be replaced by making simple physics teaching aids. One of the simple science teaching aids are one made from recycled materials. The utilization of components from the environment of students can stimulate them in learning [6]. The advantages of tools and materials from recycling from the surrounding environment are that they are easy to obtain and do not have to be purchased, are safe because they usually contain simple materials, and are easy to use as a learning resource.

Apart from being a form of supporting scientific performance in the form of practicum, Science also invites students to have superior skills, train in the implementation of research following with the scientific process, have a disciplined nature, be responsible, honest, and able to work together in a group and be able to apply their knowledge in daily life [7]. This is what makes the process skills approach indispensable because it emphasizes scientific activities in a learning process or its application in dealing with problems in everyday life. From an educational perspective, one of the process skills that needs to be developed is the ability to conclusion makings [8], [9]. Development ability process to conclusion making, the teacher can perform learning by providing opportunities for learners to explore all of the ability on every issue, as in learning that do teacher is to provide the opportunity for learners to explore their ability to collect and analyze data that is presented in full to solve a problem or problem it faces appropriately [9].

Efforts to improve process skills, especially in the ability to conclusion makings, can be made by the teacher by using the empowerment of teaching aids in learning [8]. The science teaching Aid Kit used by the teacher can explain material that is difficult for students to understand in the lesson content that has been provided. So that students will more easily understand a given material or question. The teaching aid kit can also focus the attention of students and foster interest in participating in the science learning and teaching process [10]. This implementation aims in addition to being a reminder of a material concept that may arise so that there is no misperception but also able to provide contextual understanding to students.

Considering the importance of teaching aids as the main supporting solution for practicum during the Covid-19 pandemic and also as an effort to develop scientific process skills, especially in the ability to conclusion makings. The research will be carried out to develop science teaching Aid Kit made of recycled materials as a practical solution at home during the Covid-19 pandemic to improve students' ability to conclusion makings.

\section{Method}

The research method used is the research and development method (Research and Development) by using a randomized control group pretest-posttest design. The limited trial subjects were consisting of 173 students. The sample in this study using a sampling technique is a probability sample by using cluster random sampling, two sample classes were taken, namely grade $8^{\text {th }}$-A and grade $8^{\text {th }}$-B of one of the Islamic junior high schools (MTs) in Ponorogo. This sample is a suggestion from a science subject teacher. Besides that researchers chose grade $8^{\text {th }}$-A and grade $8^{\text {th }}$-B students have the same characteristics and levels of ability. Based on this 
grade $8^{\text {th }}-\mathrm{B}$ as an experimental class and grade $8^{\text {th }}-\mathrm{A}$ as a control class. Data collection techniques used were observation, questionnaires, and tests to assess and collect data about the feasibility of pressure teaching Aid Kit. Data analysis techniques in this development are measured by instruments based on quality aspects, including: (1) Validity based expert judgement validator. (2) Effectiveness are based on the assessment of feasibility through learning oriented to the implementation of scientific improvement by using tests of students' ability to conclusion making. Next, a t-test is performed which shows a better improvement difference when using pressure teaching Aid Kit made of recycled materials.

\section{Results and Discussion}

Research and development aim to produce products and test the effectiveness of the products carried out to determine the extent to which science teaching Aid Kit Made Of Recycled Materialss are used and it is easy for students to understand the material and complete instruments related to the ability to conclusion making. Because given the importance of the ability to make students' conclusions that affect learning outcomes. So that researchers play an important role in the development of recycled substances for the ability to conclusion making students.

The results of this research and development are science teaching Aid Kit made of recycled materials and guidelines book consisting of five Aid Kit, namely trail box, hartl plane, submarine, simple hydraulic, and mystery ballon which has been validated as follows.

In addition to developing a science teaching Aid Kit made of recycled material, the researchers also developed the following guidelines books. The figure on each teaching Aid Kit use real picture pressure Aid Kit made of recycled materials, thus making the impression more interesting and foster an interest in demonstrating teaching aids in learning. As an explanation which states that science teaching Aid Kit must be made unique, so it is easy to attract the attention of students and can foster student interest in following the learning process [10]. There is a text feature as initial knowledge and introduction to students understanding the material presented. This text feature is presented by displaying events around the environment so students are expected to be able to apply learning to their daily activities. This is consistent with the theory that the learning process cannot be separated from events between individuals and the environment and student experience so that before starting new learning as a stepping stone, the teacher should try to connect it first with the learning material with student knowledge or experience. [11]. This sentence aims to motivate students to carry out the practicum to be carried out. By using the invitation sentence students are expected to be able to complete the practicum properly. This is consistent with the theory which states that motivation as a psychological factor contributes to efforts to achieve learning outcomes [12].

This practicum report is a step taken by the author to support the success of students' learning and practicum processes, it is hoped that students can easily practice their scientific approach. Such a theory reveals that using a scientific approach makes the knowledge gained by students last long and easy to remember, can improve reasoning and the ability to think freely according to his knowledge. Also, science learning, in particular, can provide a full natural science learning experience and students become more active in the teaching and learning process because the scientific approach is student-centred, thus allowing students to interact with their environment directly and experience an applicable learning process [13].

The final product of the pressure teaching Aid Kit made of recycled can be used in practical activities or as a tool in explaining the science learning concepts in substance pressure material, 
as well as being a solution in improving students' ability to conclusion making. Also, in the face of the Covid-19 pandemic, as we experience it today, home learning activities are an effective way for students to continue to gain knowledge while preventing its spread [1]. This makes the learning media, especially the material pressure teaching Aid Kit enable students to carry out learning activities independently without being bound by time and place. Thus, students become more flexible without depending on the presence of teachers. The pressure teaching Aid Kit and its book guidelines are easy to obtain and create so that they will make students aware of how much they can use to learn.

This is based on students' responses to the teaching Aid Kit and usage guidelines, it is known that their utilization gets a good response by students. The following results of the percentage of the practicality of the product are presented in Table 1. as follows.

Table 1. Practicality of Products

\begin{tabular}{lcc}
\hline \multicolumn{1}{c}{ Aspect } & Score (\%) & Conclusion \\
\hline Science Teaching Aid Kit Made of Recycled Materials & 73 & Practically \\
Guidline Book & 77 & Practically \\
Average & 75 & Practically \\
\hline
\end{tabular}

Based on this it is proven the average percentage score obtained from the practicality of the substance science teaching aid kit made of recycled materials along with their usage guidelines are $75 \%$. This score shows that the science teaching aid kit made of recycled materials is developed that is practical and can be applied or used in learning, including the Covid-19 pandemic.

This are by the reason that the science teaching Aid Kit made of recycled materials equipped with usage guidelines can make students active in the learning and teaching process that contains or carries concepts from the material being studied [14]. In other words, the science teaching Aid Kit can move as many senses as possible to an object to facilitate perception [15]. The tool is designed simply to make it easier for students to understand the material in a short amount of time which should require more time. So that students feel very helped in understanding the concepts or material pressure.

Implementation of the effectiveness test by using instrument the ability to conclusion making. The results of observations on eighth-grade students at one of the Islamic Junior High Schools (MTs) in Ponorogo are as follows.

Table 2. Test Results Capability to Conclusion Makings

\begin{tabular}{lccc}
\hline \multicolumn{1}{c}{ Indicator } & Pre Test & Post Test & N Gain \\
\hline Translating or identifying & 39 & 83 & 0.44 \\
Design or plan problem solving & 36 & 80 & 0.44 \\
Resolve the problem & 38 & 78 & 0.40 \\
Explain or evaluate results & 27 & 80 & 0.53 \\
Average & 34.75 & 80 & 0.45 \\
\hline
\end{tabular}

Based on Table 2 ability to conclusion making shows the average pretest score of 34.75 or in the category of "low or incomplete", because the value is still below the Minimum Mastery Criteria. This is different from the average posttest score which has increased in value, where the posttest has an acquisition above the Minimum Limitations Criteria, which is 80 or in the "complete" category. Whereas the $\mathrm{N}$-gain classically is 0.45 with a significant $(\alpha=0.05)$ in the moderate increase category so that it can be stated that the Aid Kit and their usage guidelines that are effectively developed increase the ability to conclusion making. 
After calculating the $\mathrm{N}$-gain classically and on each indicator the ability to conclusion making, then the writer describes descriptively quantitative. In this description, the researcher uses quantitative data. The statistic used is the Independent Sample t-Test with the sig value obtained. (2-tailed) of $0.000<0.05$, it can be stated that Ho is rejected or by the statement that there are differences in learning by using science teaching Aid Kit made reycled to the ability to conclusion making the experimental class and the control class. Because there are differences, further testing of the hypothesis is carried out to see the difference in improvement for the better. Following the results of hypothesis testing in Table 3.

Table 3. Hypothesis test results

\begin{tabular}{cccc}
\multicolumn{4}{c}{ Table 3. } \\
\hline count & t-table & $\mathbf{V}$ & Decision \\
\hline-2.37 & 1.684 & 43.82 & $\mathrm{t}$ count $<-\mathrm{t}$ table, $\mathrm{v}$ \\
\hline
\end{tabular}

Based on the decision in the Table 3 , it can be concluded that $t$-count is smaller than $t$ table, $\mathrm{v}$ so that there is a better difference in the ability to conclusion making by using a substance pressure kit than a class without using a science teaching Aid Kit made of recycled materials. This is consistent with the statement that the teaching Aid Kit can also focus on students' attention and foster interest in participating in the learning and teaching process of science that affects learning outcomes [10].

Analysis of the data that has been done on the ability to make students' conclusions, shows that students tend to have the ability to solve problems lower than the other 3 aspects. This places the ability to design or plan problem-solving and summarize or evaluate results in the same position, both from the highest or lowest order. This tendency is influenced by the ability of students to prepare for problem-solving, utilizing the solution space well and their understanding in providing answers, to be able to build students' mindset as the basis for describing the 4 aspects of ability possessed by students in the ability to conclusion making. This is the tendency of ability in one aspect. For this reason, the importance of building his ability to conclusion making so that he can become an educational product that is insightful through the scientific paradigm and can solve a problem that is understood by its capabilities.

Good student response to the science teaching Aid Kit made of recycled materials equipped with usage guidelines influences the learning process. Also, it presents the concept of teaching aids that are easy and environmentally friendly that students have never previously thought of. So that students are more active and able to improve their ability to conclusion making. This is consistent with the reason that the science teaching Aid Kit made of recycled materials is equipped with a usage guide capable of making students active in the teaching and learning process that contains or carries concepts from the material being studied. [14]. In other words, the science teaching Aid Kit made of recycled materials are able to move as many senses as possible to an object to facilitate perception [15].

The current educational paradigm requires many students to find out the source of the problem, formulate the problem, think analytically, and collaborate and collaborate to solve the problem [16], [17]. The aspect of identifying a problem or translating is an interesting aspect to discuss, because its appearance shows the value with the highest criteria compared to the other 3 aspects, so students are able to develop their skills and potential in translating or identifying problems, for that in the education it is necessary to improve the quality so that 3 other aspects can be achieved by students well. For this reason, every aspect used has a perspective that is tailored to the topic being discussed. Improving the quality of education must always be carried out by every nation so that it can progress and develop along with the development of science and technology [18]. Interaction with the learning environment that is 
governed by education through the learning process are one way that can be used to achieve these goals [19].

On the other hand on translating or identifying problems presents a picture or illustration that directs students in the analysis process to achieve a good translation and in accordance with the expectations or goals of education. Education has a significant role in the process of growth and independence in making conclusions on the students themselves [20], ie (a) Social interaction makes students able to behave the same as what is learned and responsibility for what is done so that the hope students are able to solve the problems that will or are being faced with, (b) Intelligence. Intelligence is the most important factor and has an influence on students' processes in determining attitudes, inference skills, being able to solve problems and adjust. Students who have high intelligence have a quick grasp of something that requires thinking skills, so intelligent students will sometimes be faster in making conclusions to act, as well as skills in problem analysis well to reduce the risk of what will be faced. Intelligence is very influential with the ability to conclusion makings, meaning that the higher the intelligence of students, the higher the level of the ability to conclusion makings [19]. This has led students to a success in achieving an assessment with good criteria on the ability to conclusion makings, especially aspects of translating or identifying problems.

The tendency of students to translate or identify problems are when students already understand related problems that have been packaged, so they can carry out the process of translating or identifying this well. Also, students can determine the problems they have understood. Then students determine what problems the question will be made so that in choosing the answer, students will not feel difficulties. In this case, the analysis process are done when students try to collect and understand all relevant information related to the choice of their answers that have not been achieved properly [21]. At the stage of designing or planning problem-solving students choose the strategy or method to be used in solving a problem presented. So when students look for the right solution-solution, the plan that has been made must be implemented carefully [22]. At the stage of solving a problem, students make preparations that have been there in the previous stage, namely designing and planning a solution to the problem, then analyzing to get and solving the problem under investigation. So that in making plans for solving or solving problems students can do by considering the structure of the problem and the questions that must be answered [22]. Then in the stage of explaining or evaluating the results, students' ability to express and utilize experience or data collection and the results of problem analysis to describe conclusions and be able to explain the problems that have been investigated before. Where evaluation can be stated as a systematic process in determining the level of achievement of instructional goals [23]. Also, evaluation is a systematic process for determining values based on data that has been collected through the measurement phase of all indicators. The process of making these values must be carried out objectively, and the subjective elements are not considered as consideration and assessment. In other words, it can be stated that evaluation includes the two steps ahead, namely measuring and assessing [23].

The ability to conclusion making has not been fully applied in the learning process, even though this skill is very important for students to master because it is a benchmark of the extent to which students can explore the material taught by the teacher. The ability of students to conclusion making is essential and primary in the learning process, especially in natural science lessons and is part of a standard of student independence. This is because the skill of inferring is the skill of making decisions for the state of an object based on facts, concepts, principles obtained in learning [24], so it is very influential on the results obtained by students. Reinforced in the learning objectives themselves, wherein the assessment indicators, students can understand well-related material that has been studied. Making conclusions are the main aspect 
of the results of teaching and learning processes and the development of student knowledge so that later it can be applied to face problems in daily life and technological development [25].

Almost all aspects of the ability to conclusion making have a good achievement for students in the learning process using the material pressure teaching Aid Kit and book guidance, this can be seen in the results of each indicator achievement has increased significantly. But it is different when the indicator solves problems that only have lower achievement compared to other indicators. This is influenced by aspects of completing the problem, students lack a thorough attitude, and do not have more understanding, and do not have high self-confidence so they have not tried to complete the task as well as possible. So students need to get used to practising the completion of the problems they face with as much as possible by the plans that have been made previously while considering the pattern of problems or problems they face. Like the opinion conveyed by Wardhani who stated that making a plan for solving or solving problems can be done by considering the structure of the problem and the questions that must be answered [22]. In the learning process of solving or solving problems, students are conditioned to have experience in applying various strategies for solving or solving problems.

The learning process by using a substance pressure teaching Aid Kit made of recycled materials and its user guide in improving the ability to conclusion making, educators can provide direction in learning by being allowed to explore their abilities in each of these problems based on the initial problem feature as an initial solution to a problem with students' initial abilities, because it is felt necessary to measure the level of the initial understanding of students, so that later teachers can adjust strategies in the learning process. Also, the sentence feature "Come on Practicum!" Which aims to motivate students to carry out the practicum to be carried out using a science teaching Aid Kit made of recycled materials with instructions in its usage guide. By using the invitation sentence, students are expected to be able to complete the practicum well, as expressed by Hijrawati, Khaeruddin and Nurlina in Sanjaya about good guided learning by educators by providing opportunities for students to explore their ability to collect and analyze data that is presented in full to solve a problem or problem it faces right [19].

Based on these descriptions, it is necessary to exercise for students in concluding. Starting with students who deliberately are allowed to learn interesting skills in the teaching and learning process [19]. In dealing with problems in concluding, students must be able to know themselves, then after that can determine the conditions and situations where students are, must be able to think to then end the thought process and conclusion making [26]. This is what makes the ability to conclusion making very necessarily because it emphasizes scientific activity in a learning process or its application in dealing with problems in daily life.

\section{Conclussion}

The research findings show that practically the science teaching Aid Kit made of recycled materials can be used in learning, including during the Covid-19 pandemic. In addition, it effectively increases the ability to conclusion makings in learning science grade $8^{\text {th }}$ at one of the Islamic Junior High Schools (MTs) in Ponorogo with better improvement compared to learning without using science teaching Aid Kit made of recycled materials aids and instructions for use. From the two research findings, the science teaching Aid Kit made of recycled materials and the guidelines book for its use developed is suitable for learning at home during the Covid-19 pandemic. 


\section{References}

[1] W. Fadly et al., Pendidikan Tinggi Di Masa Pandemi: Transformasi, Adaptasi dan Metamorfosis Menyongsong New Normal. Yogyakarta: Zahir Publishing, 2020.

[2] W. C. Liu and C. Y. Sitoe, "Student teachers' psychological needs, subjective experience and perceived competence in teaching during practicum," Asia Pacific J. Educ., vol. 40, no. 2, pp. 154-166, 2020, doi: 10.1080/02188791.2019.1696746.

[3] A. Atikah, Y. Sanjaya, and N. Rustaman, "The Role of Visuospatial Representation to Improve Student's Conceptual Mastery based on Gender in Learning Human Urinary System," J. Sci. Learn., vol. 1, no. 3, p. 95, 2018, doi: 10.17509/jsl.v1i3.11790.

[4] C. Zimmerman, "The development of scientific thinking skills in elementary and middle school,” Dev. Rev., vol. 27, no. 2, pp. 172-223, 2007, doi: 10.1016/j.dr.2006.12.001.

[5] W. Silalahi, "SEJ (School Education Journal) Vol. 8. No 2 Juni 2018," Upaya Meningkat. Motiv. Belajar Siswa Dengan Menggunakan Metod. Role Play Pada Pelajaran Ips Kelas Iv Sd Swasta Xaverius Padang Sidimpuan, vol. 8, no. 2, p. 112, 2018.

[6] D. Arya and A. Maul, "The building of knowledge, language, and decision-making about climate change science: a cross-national program for secondary students," Int. J. Sci. Educ., vol. 38, no. 6, pp. 885-904, 2016, doi: 10.1080/09500693.2016.1170227.

[7] P. Kurnianto and P. Dwijananti, "Pengembangan Kemampuan Menyimpulkan dan Mengkomunikasikan Konsep Fisika Melalui Kegiatan Praktikum Fisika Sederhana,” p. 4, 2010.

[8] U. N. Hamidah and F. A. M. Mubarak, "Integrative Science Education and Teaching Activity Journal," vol. 1, no. 1, pp. 1-16, 2020.

[9] H. Gresch, M. Hasselhorn, and S. Bögeholz, "Training in Decision-making Strategies: An approach to enhance students' competence to deal with socio-scientific issues," Int. J. Sci. Educ., vol. 35, no. 15, pp. 2587-2607, 2013, doi: 10.1080/09500693.2011.617789.

[10] P. Oktafiani, B. Subali, and S. S. Edie, "Pengembangan alat peraga kit optik serbaguna (AP-KOS) untuk meningkatkan keterampilan proses sains," J. Inov. Pendidik. IPA, vol. 3, no. 2, p. 189, Oct. 2017, doi: 10.21831/jipi.v3i2.14496.

[11] M. Yusup and A. Suhandi, "Pengaruh Penerapan Pembelajaran Berbasis Pengalaman Menggunakan Percobaan Secara Inkuiri terhadap Peningkatan Keterampilan Proses Sains Siswa Sekolah Dasar pada Pembelajaran IPA," EduHumaniora | J. Pendidik. Dasar Kampus Cibiru, vol. 8, no. 2, p. 211, Feb. 2017, doi: 10.17509/eh.v8i2.5144.

[12] M. Muhammad, "PENGARUH MOTIVASI DALAM PEMBELAJARAN," Lantanida J., vol. 4, no. 2, p. 87, Sep. 2017, doi: 10.22373/lj.v4i2.1881.

[13] N. M. Arumisore, S. Indana, and S. Soetjipto, "Pengembangan Perangkat Pembelajaran IPA Berbasis Pendekatan Saintifik untuk Menuntaskan Hasil Belajar Siswa Pokok Bahasan Sistem Gerak Manusia di SMP," JPPS (Jurnal Penelit. Pendidik. Sains), vol. 7, no. 1, p. 1386, Jan. 2018, doi: 10.26740/jpps.v7n1.p1386-1396.

[14] H. Riyadi, M. Wati, and S. Annur, "Pengembangan Alat Peraga Fisika Materi Cahaya untuk Melatihkan Keterampilan Proses Sains Siswa SMP,” J. Ilm. Pendidik. Fis., vol. 2, no. 1, p. 42, Feb. 2018, doi: 10.20527/jipf.v2i1.1012.

[15] R. I. Pramesty, "Pengembangan Alat Peraga Kit Fluida Statis Sebagai Media Pembelajaran Pada Sub Materi Fluida Statis di Kelas XI IPA SMA Negeri 1 Mojosari, Mojokerto," vol. 2, no. 3, p. 5, 2013.

[16] N. Winarno et al., "The Problem Of Pre-Service Science Teachers On Newton's Laws Topic: A Case Study," [Online]. Available: http://jestec.taylors.edu.my/Special Issue on 
AASEC 2018/AASEC_SIS_004.pdf.

[17] W. Fadly and P. Rochmahwati, "Kauniyah verse-based science learning: Reconstruction of the 21 th century science learning program," J. Phys. Conf. Ser., vol. 1567, no. 4, 2020, doi: 10.1088/1742-6596/1567/4/042035.

[18] "Permendikbud, 2016." .

[19] R. Sa'diyah, "Pentingnya Melatih Kemandirian Anak," J. Komun. Antar Perguru. Tinggi Agama Islam, vol. 16, no. 1, pp. 31-46, 2017.

[20] R. Sihotang, "Hubungan Antara Komunikasi dan Pengambilan Keputusan dengan Kinerja Kepala Sekolah Dasar Negeri di Wilayah Jakarta Timur,” J. Manaj. Pendidik., vol. 3, no. 2, May 2012, [Online]. Available: http://journal.unj.ac.id/unj/index.php/jmp/article/view/2434.

[21] R. G. Nurrega, H. Wahyuningsih, and U. Gusniarti, "Konseling Karir Kelompok Cognitive Information Processing Untuk Meningkatkan Pengambilan Keputusan Karir Siswa," J. Psychol. Sci. Prof., vol. 2, no. 1, p. 127, Apr. 2018, doi: 10.24198/jpsp.v2i1.16702.

[22] S. Mawaddah and H. Anisah, "Kemampuan Pemecahan Masalah Matematis Siswa pada Pembelajaran Matematika dengan Menggunakan Model Pembelajaran Generatif (Generative Learning) di SMP," vol. 3, p. 10, 2015.

[23] B. S. Aji and M. E. Winarno, "Pengembangan Instrumen Penilaian Pengetahuan Mata Pelajaran Pendidikan Jasmani Olahraga Dan Kesehatan (PJOK) Kelas VIII Semester Gasal," p. 15.

[24] S. S. Agusti, A. Danawan, A. Suhandi, and A. Amiyati, "Upaya Meningkatkan Keterampilan Peserta Didik Dalam Berhipotesis Dan Menyimpulkan Hasil Percobaan Melalui Penerapan Metode Deminter Pada Materi Fluida Statis,” p. 7, 2018.

[25] G. S. Hanggara, "Keefektifan 'Proses Guru' Sebagai Teknik Bimbingan Kelompok untuk Meningkatkan Kemampuan Pengambilan Keputusan Karier Siswa SMK,” p. 10.

[26] F. A. Al-Faraqi, "Pengaruh Kelompok Referensi dan Efikasi Diri Terhadap Pengambilan Keputusan Dalam Memilih Jurusan Kedokteran Siswa Kelas XII IPA SMAN 1 Samarinda," Psikoborneo J. Ilm. Psikol., vol. 4, p. 10, 2015. 